\title{
A Note on the Feeding Habits of Chimaera monstrosa.
}

By

\author{
G. E. Newell, B.Sc.,
}

and

H. D. G. Roper, B.Sc.,

Department of Zoology, East London College, University of London.

With 2 Figures in the Text.

Bashford Dean in his Monograph on the Chimaeroid Fishes (1906), describing the North Pacific species Chimaera colliei, states that it is omnivorous and that the "broken shells of mollusks are commonly found, as well as fragments of good sized crustaceans, as indeed the scanty literature records." He further states that " in the gut of $C$. monstrosa Faber finds crustacean and shell-fish fragments; Monticelli, quoting Lütken, Cyprina islandica; . . . Olsson finds also (and his observations are the most detailed hitherto published on the feeding of Chimaera) chætopods, amphipods, echinoids and polyps."

The following is an account of the gut contents of several specimens of Chimaera monstrosa which the authors were fortunate enough to obtain recently.

The specimens which were taken from the Atlantic Ocean sixty miles N.W. of Black Rock (Lat. $54^{\circ}$ N., Long. $12^{\circ}$ W.) at a depth of 220 to 250 fathoms, were preserved in dilute formalin.

The actual examination of the gut contents was carried out as follows.

The œsophagus and rectum were ligatured, and that part of the gut lying between the two ligatures was removed and placed in a dish of dilute formalin. The gut was then opened by a longitudinal incision, and its contents carefully transferred to the dish where they were subsequently examined by means of a binocular microscope. The food fragments were then provisionally classified, care being taken not to separate such parts as may have belonged to the same organism during life. A detailed examination of the fragments was carried out later, but because of the close similarity of the gut contents of various specimens, only three were examined in detail.

Food found in the gut of the three specimens.

Fragments of Ophiuroids. Ossicles, spines, etc.

$\begin{array}{lll}" & \text { Crustacea. } & \begin{array}{r}\text { Nostly small Malacostraca, e.g. Crabs and } \\ \text { Galatheids. Isopods were present. }\end{array} \\ \text { " } & \text { Fishes. } & \text { Muscle and cycloid scales. } \\ \text { Annelids. } & \text { Aphrodite. }\end{array}$


The remains of Ophiuroids were particularly abundant in all three specimens. Whilst parts of Crustacea were present in all three, they were only abundant in two specimens. Only one specimen contained unmistakable Annelid remains; a solitary, but almost complete specimen of Aphrodite. In addition, Gyrocotyle and Sporozoans were found as gutparasites in all the Chimaeras examined.

\section{Discussion.}

It is noteworthy that no mollusc remains were found in any of the specimens that we examined. This is possibly explained by the fact that

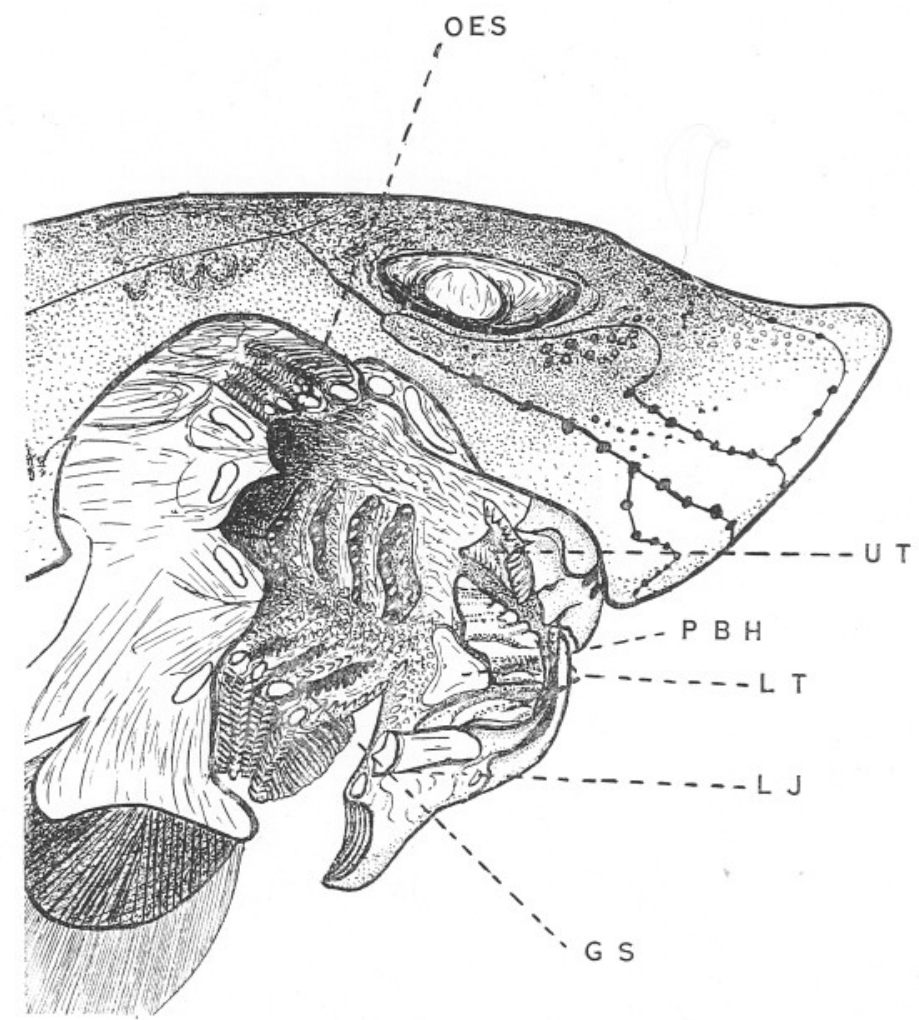

FIg. 1.-Dissection of Buccal Cavity and Pharynx.

GS, Gill-slits ; LJ, Lower-jaw ; LT, Lower-teeth ; OES, Oesophagus ; $\mathrm{PBH}$, Pad on basi-hyal; UT, Upper teeth.

our fishes were caught in relatively deeper waters than those mentioned by other observers. (Bashford Dean mentions that C. colliei swims fairly near the surface.)

From the facts obtained from examination of the gut contents and of 
the nature of the buccal cavity, it is possible to make certain inferences as to the feeding habits of the fishes.

The food-particles found in the gut are of irregular shape but never exceed three-quarters of an inch in length. In no case were recognisable portions of the "disc " of the Ophiuroids present despite the abundance of small portions of the " arms." This suggests that they had been bitten off from the " disc." From the condition of the more complete fragments of Crustacea (e.g. Crabs), too, it would appear as though the fish had seized them and bitten off certain parts (limbs) quite cleanly. Again, the presence of quite large cycloid scales and fish muscle but the complete absence of

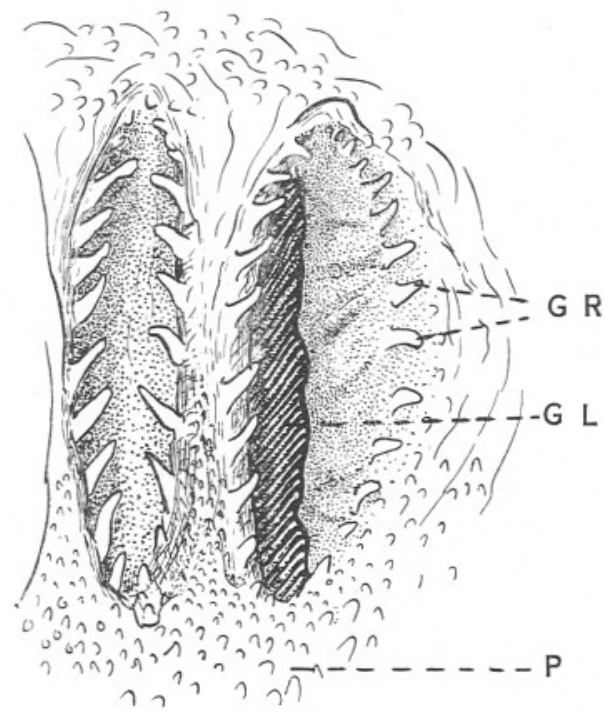

Fig. 2.-Gill Apertures 1 and 2.

GL, Gill lamella ; GR, Gill-rakers; P, Papillæ.

anything in the nature of endoskeletal parts suggests that pieces had been bitten out of the prey, possibly whilst it was still alive.

In contrast to most carnivorous fishes which swallow their prey almost whole, it seems that Chimaera bites up its food into small fragments.

To this end the teeth are admirably adapted; the sharp edges alone of the teeth of upper and lower jaws meet when the mouth closes and would suffice to shear off portions of the food. It is probable that the hard pad of tissue over the basi-hyal serves to crush food against the platelike teeth of the upper jaw. The small size of the food swallowed may possibly be accounted for by the fact that the autostylic nature of the skull and the shortness of the jaws restricts the gape of the mouth (Fig. 1).

Food particles are prevented from entering the pharyngeal apertures of 
the gills by a system of gill-rakers. These are similar to, but larger than, the papillæ on the mucous membrane lining the bucco-pharyngeal region with which they are perhaps comparable (Fig. 2). Evidence that the gillrakers are indeed modified papillæ was afforded by a microscopic examination of serial sections. The histology of both gill-rakers and papillæ was identical with the exception that the former were supported by an axis of cartilage which was not, however, connected to the branchial arch below it. In both cases, the outer layer (mucous membrane) was perforated by a system of fine canals, the structure of which is being further investigated.

\section{REFERENCE.}

Bashford Dean. 1906. Chimaeroid Fishes and their Development. Carnegie Institution of Washington, pp. 1-172. 